\title{
Sizing and Economic Analysis of Standalone PEM Fuel Cell Systems for Residential Utilization
}

\author{
Sherif M. Imam \\ The Electrical Engineering Department, \\ Faculty of Engineering, Kafrelsheikh University \\ Kafrelsheikh, Egypt \\ (Sherif_imam@eng.kfs.edu.eg)
}

\author{
Ahmed M. Azmy \\ Electrical Power and Machines Engineering Department, \\ Faculty of Engineering, Tanta, University, \\ Tanta, Egypt \\ (azmy@f-eng.tanta.edu.eg)
}

\begin{abstract}
This study discusses the economic utilization of proton exchange membrane fuel cell (PEMFC) based on cost of energy (COE) to supply residential electrical and thermal loads. The fuel cell system is sized using simplified mathematical expressions considering the stack degradation and the system salvage value at the end of its life time. The study is based on a 5 $\mathrm{kWh} /$ day residential loads with a peak load power of $1300 \mathrm{~W}$. Two scenarios for economic survey are studied. The first scenario is to find the commercial price for each FC component considering that the supply fuel is hydrogen. The other scenario is for a complete $\mathrm{FC}$ system commercial price considering that the supply fuel is natural gas. The economic analyses are based on the actual sale prices in the market. The COE of the fuel cell system is compared with previous work by the authors for the same residential ratings but supplied from a stand-alone photo voltaic system (SAPV). The analysis results show that the COE relies heavily on the capital cost of the system.
\end{abstract}

Index Terms - PEMFC unit sizing, Cost of energy, Economic analysis, FC degradation.

\begin{tabular}{|clc|}
\hline \multicolumn{2}{|l}{ List of symbols } & Unit/value \\
Symbol & Description & $\mathrm{cm}^{2}$ \\
\hline $\mathrm{A}_{\text {cell }}$ & The cell area & $\$$ \\
\hline $\mathrm{C}_{\mathrm{AO} \& \mathrm{M}}$ & Annual O\&M cost & $\$$ \\
\hline $\mathrm{C}_{\mathrm{C}}$ & The capital cost of the FC & $\$ / \mathrm{MMBtu}$ \\
\hline $\mathrm{C}_{\mathrm{HG}}, \mathrm{C}_{\mathrm{NG}}$ & Hydrogen and natural gas costs & $\$ / \mathrm{Wh}$ \\
\hline $\mathrm{COE}$ & Cost of energy & $\mathrm{cal} / \mathrm{gm} . \mathrm{K}$ \\
\hline$C_{P}^{1}, C_{P}^{2}$ & $\begin{array}{l}\text { Average specific heat of cooling } \\
\text { fluid of the FC stack and water }\end{array}$ & $\$$ \\
\hline $\mathrm{C}_{\mathrm{R}}$ & Running cost of the FC per year & \\
\hline $\mathrm{C}_{\mathrm{th}}$ & Number of thermal cycles & $\%$ \\
\hline $\mathrm{d}$ & Interest rate & $\mathrm{Wh}$ \\
\hline $\mathrm{D}_{\mathrm{e}}, \mathrm{D}_{\mathrm{th}}$ & $\begin{array}{l}\text { Electrical and thermal } \\
\text { degradation }\end{array}$ & $\mathrm{power}$ \\
\hline $\mathrm{E}_{\mathrm{e}}, \mathrm{E}_{\mathrm{th}}$ & FC electrical and thermal energy & $\mathrm{Wh} / \mathrm{day}$ \\
\hline $\mathrm{E}_{\mathrm{L}}$ & Average electrical load & 96485 \\
\hline $\mathrm{F}$ & Faraday constant & $\mathrm{C} / \mathrm{mol}$ \\
\hline $\mathrm{g}_{\mathrm{m}}$ & Molar mass of hydrogen \\
\hline
\end{tabular}

\begin{tabular}{|c|c|c|}
\hline $\mathrm{h}_{\mathrm{fc}}$ & FC running hours & $\mathrm{h}$ \\
\hline $\mathrm{H}_{2, \text { in }}$ & $\begin{array}{l}\text { The amount of hydrogen introduced } \\
\text { to the fuel cell }\end{array}$ & $\mathrm{g}$ \\
\hline $\mathrm{H}_{2, \text { out }}$ & $\begin{array}{l}\text { The amount of unconsumed } \\
\text { hydrogen in the fuel cell }\end{array}$ & $\mathrm{g}$ \\
\hline $\mathrm{I}$ & The FC rated current & A \\
\hline $\mathrm{I}_{\mathrm{C}}$ & Current capacity & Ah \\
\hline $\mathrm{j}$ & The current density & $\mathrm{A} / \mathrm{cm}^{2}$ \\
\hline LLC & Life cycle cost & $\$$ \\
\hline$\dot{\mathrm{M}}_{1}, \dot{\mathrm{M}}_{2}$ & $\begin{array}{l}\text { Mass flow rates of coolant fluid in } \\
\text { the heat exchanger and water }\end{array}$ & $\mathrm{gm} / \mathrm{s}$ \\
\hline $\mathrm{m}_{\mathrm{H} 2}$ & The hydrogen flow rate & $\mathrm{g} / \mathrm{min}$ \\
\hline $\mathrm{M}_{\mathrm{H} 2 \mathrm{O}}$ & Water molecular weight & $\begin{array}{c}0.018 \\
\mathrm{Kg} / \mathrm{mol}\end{array}$ \\
\hline $\mathrm{m}_{\mathrm{w}}$ & $\begin{array}{l}\text { The mass flow rate of the water in } \\
\text { the humidifier }\end{array}$ & $\mathrm{Kg} / \mathrm{s}$ \\
\hline $\mathrm{n}$ & Number of moles of a substance & Mol \\
\hline $\mathrm{N}_{\text {Cell }}$ & The number of cells & \\
\hline $\mathrm{n}_{\mathrm{e}}$ & $\begin{array}{l}\text { Number of electrons per second for } \\
1 \text { amper }\end{array}$ & $6.28 \mathrm{E}+18$ \\
\hline $\mathrm{nem}_{\mathrm{em}}$ & $\begin{array}{l}\text { Number of electrons per each } \\
\text { molecule of hydrogen }\end{array}$ & 2 \\
\hline $\mathrm{n}_{\mathrm{mm}}$ & $\begin{array}{l}\text { Number of molecules per hydrogen } \\
\text { mol }\end{array}$ & $6.02 \mathrm{E}+23$ \\
\hline $\mathrm{P}$ & $\begin{array}{l}\text { The pressure of the hydrogen in a } \\
\text { tank }\end{array}$ & Atm \\
\hline $\mathrm{P}_{\mathrm{e}}$ & The rated electrical power of the FC & $\mathrm{W}$ \\
\hline $\mathrm{P}_{\mathrm{m}}$ & The maximum load power & $\mathrm{W}$ \\
\hline $\mathrm{P}_{\text {th }}$ & The rated thermal power of the FC & $\mathrm{W}$ \\
\hline $\begin{array}{l}Q_{a b s 1}, \\
Q_{a b s 2}\end{array}$ & $\begin{array}{l}\text { Absorbed thermal power by cooling } \\
\text { fluid of the fuel cell and water }\end{array}$ & $\mathrm{cal} / \mathrm{s}$ \\
\hline $\mathrm{R}$ & The gas constant & $\mathrm{atm} / \mathrm{mol} . \mathrm{K}$ \\
\hline SV & Salvage value of the FC system & $\$$ \\
\hline $\mathrm{T}$ & The temperature of hydrogen & $\mathrm{K}$ \\
\hline$T_{1 c}, T_{2 c}$ & $\begin{array}{l}\text { Cold temperature of the fuel-cell } \\
\text { cooling fluid and water }\end{array}$ & $\mathrm{K}$ \\
\hline$T_{1 h}, T_{2 h}$ & $\begin{array}{l}\text { Hot temperatures of the fuel-cell } \\
\text { cooling fluid and water }\end{array}$ & $\mathrm{K}$ \\
\hline
\end{tabular}




\begin{tabular}{|clc|}
\hline $\mathrm{U}_{\mathrm{f}}$ & Utilization factor & $\%$ \\
\hline $\mathrm{V}_{\text {cell }}$ & The cell voltage & $\mathrm{V}$ \\
\hline $\mathrm{V}_{\mathrm{H} 2}$ & Hydrogen tank volume & liters \\
\hline $\mathrm{V}_{\mathrm{st}}$ & The stack voltage & $\mathrm{V}$ \\
\hline $\mathrm{y}$ & The life time of FC in years & years \\
\hline$\eta_{\mathrm{DC} / \mathrm{AC}}$ & The efficiency of DC/AC inverter & $\%$ \\
\hline$\eta_{\mathrm{e}}$ & Electrical efficiency of CHP plant & $\%$ \\
\hline$\eta_{\text {th }}$ & Thermal efficiency of CHP plant & $\%$ \\
\hline$\mu_{\mathrm{FC}}$ & Margin coefficient for FC sizing & 1.1 \\
\hline$\mu_{\mathrm{V}}$ & $\begin{array}{l}\text { Margin coefficient for hydrogen } \\
\text { tank sizing }\end{array}$ & 1.1 \\
\hline$\phi$ & Inlet air humidity coefficient & $\%$ \\
\hline
\end{tabular}

\section{INTRODUCTION}

Fuel cell (FC) is one of the most efficient energy conversion devices. It is used to convert chemical reaction into electrical power. Simple FC consists of anode, cathode, and membrane. Fuel, such as hydrogen, is fed to the anode and the oxygen is fed to the cathode. The membrane is used to prevent electrons flow between the electrodes and to prevent hydrogen and oxygen from direct mixing.

There are many types of FC, where each type has its advantages and disadvantages [1]. In this paper, the PEMFC will be used. In PEMFC, the feeding hydrogen molecule at the anode is split into hydrogen ions and two electrons. Both the hydrogen and the two electrons move to the cathode. The hydrogen moves to the cathode through the membrane, while and the two electrons move through the load. At the cathode, the feeding oxygen combines with the hydrogen and the electrons to produce water. The reaction equations are as follows:

$$
\begin{aligned}
& \text { Anode reaction: } 2 \mathrm{H}_{2} \Rightarrow 4 \mathrm{H}^{+}+4 e^{-} \\
& \text {Cathode reaction: } \mathrm{O}_{2}+4 \mathrm{H}^{+}+4 e^{-} \Rightarrow 2 \mathrm{H}_{2} \mathrm{O} \\
& \text { Overall cell reaction: } 2 \mathrm{H}_{2}+\mathrm{O}_{2} \Rightarrow 2 \mathrm{H}_{2} \mathrm{O}
\end{aligned}
$$

The PEMFC has low operating temperature between $60{ }^{\circ} \mathrm{C}$ and $100{ }^{\circ} \mathrm{C}$. Its electrical efficiency is between $40 \%$ and $50 \%$ and it has fast start-up process. Since it has no moving parts in the stack, it requires minimum maintenance. However, it has high cost and low durability for practical applications [1].

A review of PEMFC technologies and applications are introduced in [2]. The amount of hydrogen and the tank size are introduced in [3]. However, this research didn't pay attention to neither fuel utilization nor cell voltage. One of the challenges in fuel cell performance is the water management for the humidifier. A review of water management techniques and experimental setup for reliable humidifier were presented in [4]. The relative humidity of the gas and the pressure changes in the system have been considered in [4], but it didn't pay attention neither to the accumulated water at the cathode nor the load current.

Controlling the stack temperature of the fuel cell is a critical issue. High temperature reduces the humidification and thus leads to reducing both the proton conductivity and the membrane lifetime. On the other hand, low temperature increases the condensation of water at the cathode causing voltage losses and limiting the load current [5]. A review of different cooling techniques for PEMFC and the advantages and disadvantages of each technique are introduced in [6]. The analysis of the relation between the temperature of the heat exchanger inlet coolant fluid and acceptable temperature difference across the fuel cell taking into consideration the heat exchanger effectiveness value is introduced in [7]. The technical and economic feasibility of using micro combined heat and power (CHP) fuel cell for different climate zones of Iran is studied in [8]. However, the degradation in the electrical and the thermal power of the fuel cell did not considered in this research. A comparison of degradation behaviours for open-ended and closed PEMFC and a review on performance degradation during start up and shutdown processes are provided in [9] and [10] respectively.

This paper aims to introduce a sizing methodology and to analyse the economics of PEMFC system for residential utilization. The economic study considers the value of cell voltage and the utilization factor when calculating the flow rate of supplying fuel. FC degradation and the system salvage value are taking into consideration for the life cycle cost "LCC". Each subsystem is sized using simplified mathematical expressions. Two scenarios for economic survey are studied. The first one is based on finding the commercial price for each FC component considering that the supply fuel is hydrogen. The other scenario is for a complete FC system commercial price considering that the supply fuel is natural gas. The COE is investigated for each system and compared with previous work by the authors for the same residential ratings but supplied from a stand-alone photo voltaic system (SAPV).

\section{SiZING MethodOLOGY}

The sizing procedures adopted for stand-alone PEMFC system are performed as follows:

\section{A. Defining the electrical load}

A residential load is analyzed as shown in table 1 to define its average daily consumption. In the table, the average electrical load $\left(\mathrm{E}_{\mathrm{L}}\right)$ for a household is about $5 \mathrm{kWh} /$ day.

Table 1: Electrical load of the PEMFC power system

\begin{tabular}{l|ccccc}
\hline Appliance & Number & $\begin{array}{c}\text { Power } \\
{[W]}\end{array}$ & $\begin{array}{c}\text { Total } \\
\text { power } \\
{[W]}\end{array}$ & $\begin{array}{c}\text { Working } \\
\text { hours } \\
{[\text { h/day }]}\end{array}$ & $\begin{array}{c}\text { Total } \\
\text { Energy } \\
{[\text { Wh/day] }}\end{array}$ \\
\hline Ceiling fan & 2 & 60 & 120 & 5 & 600 \\
Lamps & 6 & 40 & 240 & 6 & 1440 \\
Refrigerator & 1 & 175 & 175 & 6 & 1050 \\
TV & 1 & 150 & 150 & 3 & 450 \\
Water pump & 1 & 245 & 245 & 3 & 735 \\
Washing & 1 & 370 & 370 & 2 & 740 \\
machine & & & 1300 & & 5015 \\
Total & & & &
\end{tabular}




\section{B. Determination of PEMFC size}

The maximum load power must be covered by the FC stack. The rated power of the FC can be calculated as follows [11]:

$$
P_{e}=\mu_{F C} \frac{P_{m}}{\eta_{D C / A C}}
$$

According to the FC characteristics, the cell voltage of the stack is a function of the current density as illustrated in Fig. 1. The stack of the FC can be sized as follows [12]:

$$
\begin{aligned}
& P_{e}=V_{s t} \times I \\
& I=j \times A_{\text {cell }} \\
& V_{\text {st }}=V_{\text {cell }} \times N_{\text {cell }}
\end{aligned}
$$

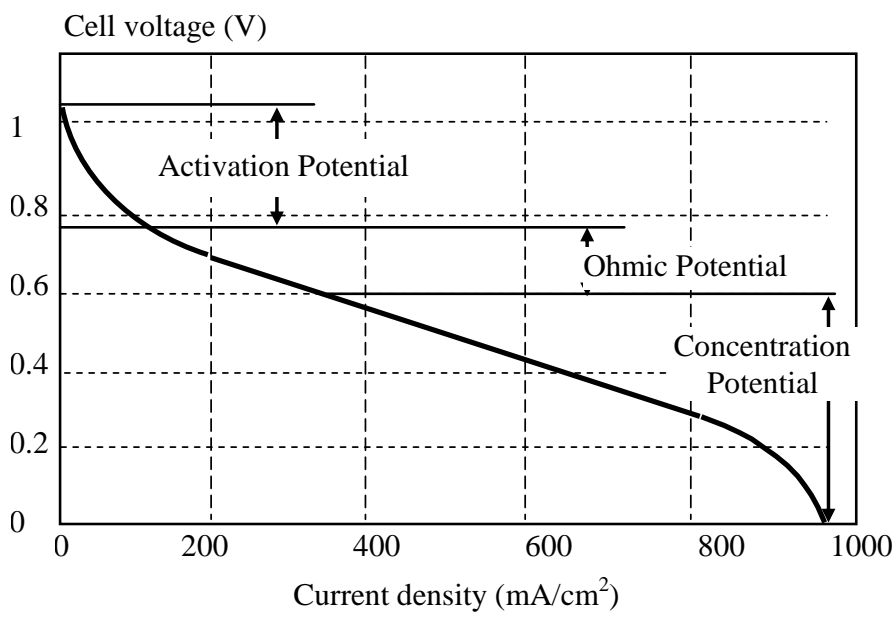

Fig. 1: The relationship between the cell voltage and the cell current density

\section{Determination of hydrogen consumption}

The energy content of hydrogen is measured by hydrogen's lower heating value (LHV) [3]. The amount of hydrogen's LHV stored in the tank should equal to the equivalent electrical energy needed by the load. From (1), each molecule of hydrogen gives two electrons. Thus, by identifying the load current, it is possible to get the required amount of hydrogen since one Amper represents one coulomb per second and the charge of a single electron is $1.602 \times 10^{-19}$ coulombs. The required amount of hydrogen flow rate can be calculated according to the following equations [13]:

$$
\begin{aligned}
& E_{L}=V_{\text {Cell }} \times I_{C} \\
& m_{H_{2}}=\frac{60 \times E_{L} \times n_{e} \times g_{m}}{V_{\text {Cell }} \times n_{e m} \times n_{m m}}
\end{aligned}
$$

Due to incomplete reaction of hydrogen at the anode and the opened-end stack of the fuel cell, the consumed hydrogen is less than the total hydrogen introduced into the fuel cell. A utilization factor $\left(\mathrm{U}_{\mathrm{f}}\right)$ is defined as the fraction of the total fuel or oxidant introduced into a fuel cell that reacts electrochemically. The utilization factor can be introduced as follows [13]:

$$
U_{f}=\frac{H_{2, \text { in }}-H_{2, \text { out }}}{H_{2, \text { in }}}
$$

Concerning the utilization factor, (9) should be modified as follows:

$$
m_{H_{2}}=\frac{60 \times E_{L} \times n_{e} \times g_{m}}{U_{f} \times V_{\text {Cell }} \times n_{e m} \times n_{m m}}
$$

\section{Determination of hydrogen tank size}

The volume of the hydrogen tank can be determined from the ideal gas law as follows [3]:

$$
V_{H_{2}}=\frac{n \times R \times T}{P}
$$

The volume of the hydrogen in the tank is controlled by both the temperature and the pressure. PEMFC operates at low temperatures between $60^{\circ} \mathrm{C}$ and $100^{\circ} \mathrm{C}$. This means that the hydrogen has to be released from the tank at this temperature range. The suitable pressure for this range of temperature is 110 bars, which limits the output flow rate of hydrogen below $2 \mathrm{~g} / \mathrm{s}$, and consequently, limits the power of the PEMFC below $10 \mathrm{~kW}$ [14]. The tank size has to be multiplied by a margin factor due to the unexpected circumstances of both excessive pressure fluctuation and temperature rising. The margin factor " $\mu_{V}$ " ranges are from 1.1 to 1.3 [15]. Thus, (12) should be modified as follows:

$$
V_{H_{2}}=\mu_{V} \frac{n \times R \times T}{P}
$$

\section{E. Determination of the humidifier size}

The fuel cell membrane should have moderate water content. High water content in the membrane has the advantage of increasing the proton conductivity since it decreases the ohmic loss, and consequently, increases the lifetime of the membrane. On the other hand, the high water content in the membrane results in high water accumulation in the cathode, which decreases the oxygen flow. Decreasing the oxygen flow will limit the load current [16]. The humidifier works by passing the hydrogen and oxygen through a flow of hot water vapor saturated with fine bubbles. The mass flow rate of the water in the humidifier can be calculated as follows considering the accumulated water at the cathode and the load current [16]:

$$
m_{W}=1.19 \lambda \phi \frac{N_{\text {cell }} I}{F} M_{H_{2} O}
$$

\section{$F$. The heat exchanger sizing}

To control the temperature in PEMFC and maximize its economic benefits, a heat exchanger has to be used. The crux of heat exchanger operation is to transfer heat from warm exit coolant to the cool inlet coolant by controlling the flow rate of the coolant circulation to obtain the desired operating temperature. After certain time of circulation process, the coolant inlet temperature will reach a steady state condition. This settling time depends on the heat exchanger effectiveness and both temperature of coolant and the desired operating 
temperature of the fuel cell. The heat exchanger effectiveness is a ratio of the actual rate of heat transfer between the hot and cold fluids to the maximum possible heat transfer rate [7]. The maximum possible heat transfer rate is obtained from an infinitely sized heat exchanger [7]. The cooling method depends on the rated power of the fuel cell. For power rating below $2 \mathrm{~kW}$, the stack can be cooled by air, which is different from the cathode air. For power ratings greater than $10 \mathrm{~kW}$, water is used for the cooling process [17].

The exhaust heat from PEMFC can be used in preheating both water and space for residential usages. A detailed design of the heat exchanger was mentioned in [18].

This study concentrates on the economic benefit of using the exhaust heat from the PEMFC in preheating residential water usages as shown in Fig. 2. The equations describing the operation of the heat recovery system can be illustrated as follow [18]:

$$
\begin{aligned}
& Q_{a b s 1}=\dot{M}_{1} \times C_{P}^{1} \times\left(T_{1 h}-T_{1 c}\right) \\
& Q_{a b s 2}=\dot{M}_{2} \times C_{P}^{2} \times\left(T_{2 h}-T_{2 c}\right)
\end{aligned}
$$

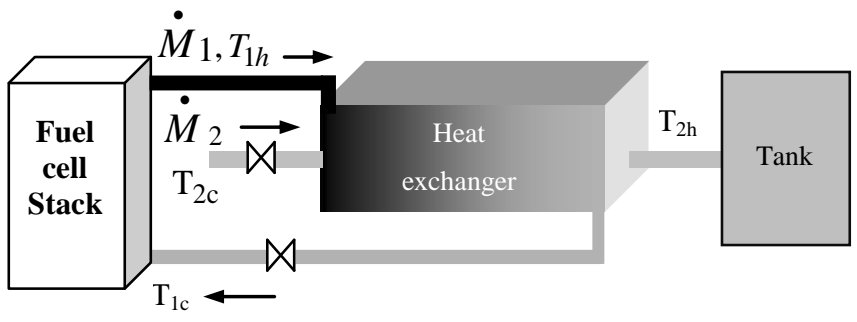

Fig. 2: Block diagram of a simple heat recovery system

\section{G. Fuel cell auxiliary components}

The auxiliary components in the fuel cell system or the balance of plant (BOP) as it may be called consist of air filtration and compressor, pressure relief valves, water pumps, heat exchanger and sensors. The air filtration system is used for removal of particular matter and contaminants such as sulfur, salts, carbon monoxide and hydrocarbons. The compressor is used to supply pressurized air for the PEMFC at the cathode. The water pumps are used for humidification and temperature coolant circulation. The hydrogen fueling system consists of blower, ejector and purge valve. Both the blower and ejector are used to control the feed of hydrogen to the anode of the fuel cell stack. The blower is used for flow rates below $25 \%$ of the rated capacity, while the ejector is used for flow rates between $25 \%$ and $100 \%$ of the rated capacity. The low temperature of the liquid hydrogen causes the atmospheric air to condensate. The partial evaporation of nitrogen can cause the liquid air to become enriched with oxygen. In addition, it will act as a fire agent when contacts with any combustible substances. For this reason, at high hydrogen flow rate, a purge valve is used for mixing a safe percentage value of hydrogen with cathode exhaust air to minimize the dilution effects of nitrogen crossover [19].

\section{THE LIFE-CYCLE COST}

PEMFC has an average lifetime ranging of 3000-5000 operating hours in passenger vehicles systems, while it has an average lifetime of 40000-80000 operating hours in stationary power systems. The life cycle cost of the PEMFC system depends heavily on both the capital cost of the fuel cell and the running cost of the fueling system. The capital cost of the PEMFC relies heavily on its output power and the volume of manufacturing per year [20]. The cost of fuel, which in final form is hydrogen, depends on its production method [21]. The LCC can be calculated depending on the capital cost, the present value of the running cost during its life time, operation and maintenance cost (O\&M) and the salvage value at the end of its life. The capital cost of the FC system includes the FC stack, storage tank, BOP, and the inverter. The LCC of the PEMFC system can be calculated from the following equation [22]:

$$
L C C=C_{C}+C_{O \& M}+\sum_{y=1}^{Y} \frac{C_{R}}{(1+d)^{y}}-\frac{S V}{(1+d)^{Y}}
$$

The O\&M cost depends on the FC generated energy. Thus the present value of the annual O\&M cost can be calculated and introduced in (17) as follows:

$$
L C C=C_{C}+\sum_{y=1}^{Y} \frac{C_{A O \& M}}{(1+d)^{y}}+\sum_{y=1}^{Y} \frac{C_{R}}{(1+d)^{y}}-\frac{S V}{(1+d)^{Y}}
$$

The electrical and thermal energy of the CHP fuel cell can be calculated from the following equations [8]:

$$
\begin{aligned}
& E_{e}=P_{e} \times h_{f c} \\
& E_{t h}=P_{t h} \times h_{f c} \\
& P_{t h}=P_{e} \frac{\eta_{t h}}{\eta_{e}}
\end{aligned}
$$

Equations (19) through (21) did not take into account the effect of degradation on the fuel cell output. The causes of fuel cell degradation are the non completed humidified gases at the anode and cathode, the high temperature of the fuel cell and cathode carbon corrosion [23]. The degradation can involve one or all fuel cell components like electrolyte, electrodes and bipolar plates. The degradation in the fuel cell can be measured by one of the following units: the percentage loss relative to the initial value of efficiency, power, current or voltage. The common measuring unit of fuel cell degradation is the voltage loss per unit time (typically $\mu \mathrm{V} / \mathrm{h}$ ). The degradation rate in the fuel cell depends on many factors such as the fuel cell type, the operating voltage and current density, maximum output power, fuel type, operating conditions, and the running hours. Cumulative degradation for small ratings below $2 \mathrm{~kW}$ can be expressed as a percentage performance loss per MWh electrical energy output, and per 1000 thermal cycles. The degradation ranges are between $0.16 \%$ and $8 \%$ per $1000 \mathrm{~h}$ for PEMFCs for electrical power, and between $0 \%$ to 
$10 \%$ performance degradation per 1000 thermal cycles for thermal power [24].

Concerning the effect of degradation on FC output, the electrical energy of the CHP fuel cell will be as follows:

$$
E_{e}=\sum P_{e} h_{f c}\left[1-\left(\text { floor } \frac{h_{f c}}{10^{3}}\right) D_{e}\right]
$$

where floor means rounds down the fraction to the nearest integer number.

The thermal cycle means cycling from FC operating temperature to cold temperature and back to operating temperature again. Larger systems can be exposed to a few thermal cycles throughout their life as they operate for longer periods between shutdowns. For the smaller PEMFC, the unit has to be stopped approximately every $600 \mathrm{~h}$ [24].

The COE can be calculated by dividing the life cycle cost of the system over the total generated energy, included the electrical and thermal energy, during the system life cycle as follows:

$$
C O E=\frac{L C C}{E_{e}+E_{t h}}
$$

\section{RESUlTS AND Discussions}

A commercial market survey is done to introduce the COE through the fuel cell system price. Two survey scenarios are studied. According to the available prices in the commercial market, one scenario is to find each FC component price, and the other scenario is for a complete FC system price. It is supposed that the first scenario will use hydrogen directly to feed the FC, while the second scenario will use the natural gas to feed the FC through a reformer.

\section{A. The first senario}

Table 2 illustrates the ratings; specifications and the cost of the PEMFC stack [25]. The data of table 2 are analysed and it is concluded that, the average cost of PEMFC stack is about $3500 \$ / \mathrm{kW}$ as appears from the curve slop of Fig. 3. The stack efficiency is between $35 \%$ and $45 \%$ according to the consumed hydrogen to the produced power when the power density of $\mathrm{H}_{2}$ is $65.8 \mathrm{Wh} / \mathrm{mole}$, and the hydrogen consumption occurs at 0.5 bar $\& 30 \mathrm{C}^{\circ}$.

Table 2: PEMFC stack specifications and cost.

\begin{tabular}{l|lcccc}
\hline $\begin{array}{c}\text { Stack } \\
\text { rating }[W]\end{array}$ & $\begin{array}{c}\text { Max. } \\
\text { O/P Power }\end{array}$ & $\begin{array}{c}\text { No. of } \\
\text { cells }\end{array}$ & $\begin{array}{c}\text { Dim. } \\
{[\mathrm{cm}]}\end{array}$ & $\begin{array}{c}\mathrm{H}_{2} \text { Cons. } \\
{[\mathrm{L} / \mathrm{min}]}\end{array}$ & $\begin{array}{c}\text { Price } \\
{[\$]}\end{array}$ \\
\hline 5000 & $72 \mathrm{~V} / 70 \mathrm{~A}$ & 120 & $38 \times 16 \times 46$ & 70 & 15000 \\
3000 & $43.2 \mathrm{~V} / 70 \mathrm{~A}$ & 72 & $38 \times 16 \times 28$ & 42 & 10500 \\
2000 & $28.8 \mathrm{~V} / 70 \mathrm{~A}$ & 48 & $38 \times 16 \times 20$ & 28 & 7500 \\
1000 & $43 \mathrm{~V} / 23.5 \mathrm{~A}$ & 72 & $32.4 \times 22 \times 12.2$ & 14 & 4000 \\
500 & $21 \mathrm{~V} / 24 \mathrm{~A}$ & 36 & $25 \times 19 \times 7.5$ & 6.5 & 3435 \\
300 & $43 \mathrm{~V} / 7 \mathrm{~A}$ & 72 & $32.4 \times 10.9 \times 9.4$ & 3.9 & 2450 \\
200 & $28 \mathrm{~V} / 7.2 \mathrm{~A}$ & 48 & $22.3 \times 10.9 \times 9.4$ & 2.8 & 1780 \\
100 & $14 \mathrm{~V} / 7.2 \mathrm{~A}$ & 24 & $14.3 \times 10.9 \times 9.4$ & 1.3 & 1029 \\
30 & $9 \mathrm{~V} / 3.4 \mathrm{~A}$ & 12 & $8 \times 6.4 \times 4.6$ & 0.42 & 742 \\
20 & $7.8 \mathrm{~V} / 2.6 \mathrm{~A}$ & 13 & $7.6 \times 6.4 \times 4.7$ & 0.28 & 433 \\
12 & $7.8 \mathrm{~V} / 1.6 \mathrm{~A}$ & 13 & $7.6 \times 6.4 \times 4.7$ & 0.18 & 347 \\
\hline
\end{tabular}

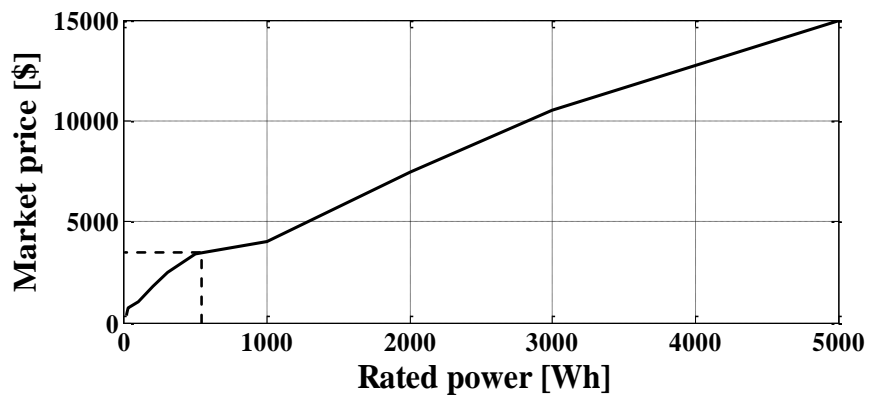

Fig. 3: The relationship between the PEMFC stack rating and its capital cost.

The most popular metal hydrides SOLID-H, hydrogen storage, containers supply hydrogen in low atmospheric pressure at room temperature. This is the safest method known for storing flammable hydrogen gas. Typical SOLID-H container sizes are given in table 3. Metal hydrides are the most compact way to store hydrogen (more dense than liquid hydrogen). The lower cost SOLID-H CL-series containers, including CL-370 and CL-910, are based on aluminum industrial gas cylinders. These two containers hold 370 and 910 liters of hydrogen respectively. The aluminum cylinders used to construct the CL-series are rated for very high pressures. This makes them heavier than equivalent thin walled stainless steel BL-series containers of comparable capacity [26].

Table 3: SOLID-H containers size and cost.

\begin{tabular}{l|cc}
\hline \multicolumn{1}{c|}{ Model } & Size [Litters] & Cost [\$] \\
\hline BL-18 & $18-20$ & 345 \\
BL-30 & $30-34$ & 675 \\
BL-60 & $60-69$ & 991 \\
BL-120 & $120-135$ & 1523 \\
BL-220 & $220-242$ & 2337 \\
BL-740 & $740-822$ & 3139 \\
CL-370 & $334-370$ & 525 \\
CL-910 & $819-910$ & 1320 \\
\hline
\end{tabular}

The most economical sources to produce hydrogen are coal and natural gas. The linking equation between both the cost of hydrogen and natural gas is as follow [21]:

$$
C_{H G}=1.27 \times C_{N G}+0.985
$$

The average natural gas residential price for the last twelve months is 12.62 dollars per thousand cubic feet according to Energy Information Administration, U.S. natural gas prices [27]. The same price can be obtained from linking the cost of hydrogen to the cost of gasoline, where the energy content of one kilogram of hydrogen equal the energy content in one gallon of gasoline. A computer program has been developed to analyze the COE over the system life time. Table 4 illustrates the parameters values that are used in the program, where the following assumptions are taking into consideration in the programming [8], [13], [22], [28], [29]:

Table 4: The setting parameters of the computer program. 


\begin{tabular}{l|c}
\hline \multicolumn{1}{c|}{ Parameter } & Setting value \\
\hline Peak load power & $1300 \mathrm{~W}$ \\
Total energy & $5 \mathrm{KWh} / \mathrm{day}$ \\
The inverter efficiency & $90 \%$ \\
Margin coefficient for FC sizing & 1.5 \\
Stack single cell voltage & $0.65 \mathrm{~V}$ \\
Current density & $0.65 \mathrm{~A} / \mathrm{cm}^{2}$ \\
Single cell area & $7.5 * 7.5 \mathrm{~cm}^{2}$ \\
Utilization factor & 0.8 \\
FC life time & $60000 \mathrm{~h}$ \\
FC running time & $8760 \mathrm{~h} / \mathrm{year}$ \\
Interest rate & $6 \%$ \\
Electrical degradation in FC & $2 \%$ per $1000 \mathrm{~h}$ \\
Thermal to electrical power ratio & $140 \%$ \\
\hline
\end{tabular}

1-) The O\&M cost is $0.035 \$ / \mathrm{kWh}$.

$2-)$ The FC salvage value is $10 \%$ of its capital cost.

3-) The BOP including the heat exchanger cost is about $40 \%$ of the FC capital cost for 500,000 units per year production volume.

In support of accurate calculations, the degradation in FC output affects only the total generated energy not the hydrogen or natural gas consumption. The thermal degradation in PEMFC has been neglected as it will not exceed 150 thermal cycles per its life. The results show that the mass flow rate of water in the humidifier is $1.17 \mathrm{l} / \mathrm{hr}$. The low flow humidification system cost is $\$ 1700$ [30]. The hydrogen flow rate is $0.14 \mathrm{Kg} / \mathrm{hr}$. The corresponding hydrogen tank is CL910.

The capital cost of the fuel cell system is about $9250 \$ / \mathrm{kW}$ and the COE equal $0.19 \$ / \mathrm{kWh}$ including the electrical and thermal output power of the fuel cell. The pie-chart illustrated in Fig. 4 shows the percentage cost of each component of the FC system within its life time. The analysis shows that hydrogen cost represents the major COE which equals $43 \%$, while cost of power conditioning inverter and the hydrogen tank represent only $8 \%$ of the whole cost. The percentage cost of the stack and the BOP are almost equals.

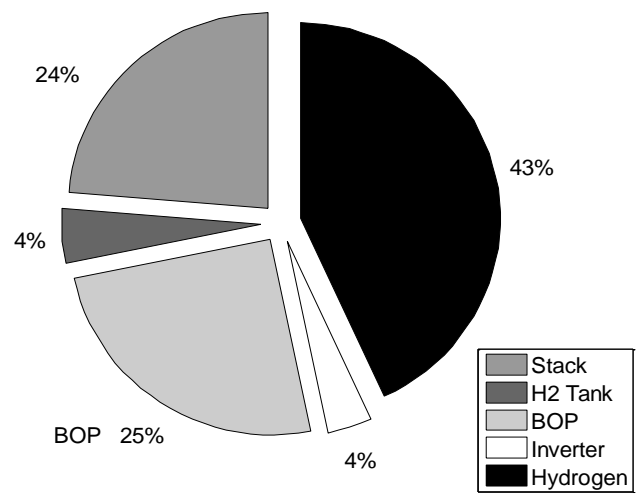

Fig. 4: The percentage cost of each component of the FC system within its life time.

\section{B. The second senario}

Following is another survey of the complete CHP PEMFC systems in the commercial market. These systems are produced with all required components such as: stack, heat exchanger, hydrogen storage tank and the BOP. The commercial system also includes its reformer to produce the required hydrogen from the natural gas.

The Japanese government has supported the residentialbased ENE-FARM CHPFC since 2009. By the end of 2012, 34,000 of the natural gas-powered fuel cell systems had already been installed. The product specifications vary somewhat from company to company. The new model of ENE-FARM, which is launched in the market from the first of April 2014, is typically sold at rated electrical and thermal outputs of $0.75 \mathrm{~kW}$ and $1.08 \mathrm{~kW}$ respectively, with a total, electric and thermal, efficiency ranging from $80 \%$ to $95 \%$ regarding to the low heating value of hydrogen. The life time of the system is 60000 hours and its price is about $\$ 18500$ [31].

Like the ENE-FARM program in Japan, the ENE-FIELD program is supported by the government, co-funded by the partners and the European Commission's Fuel Cells and Hydrogen Joint Undertaking program (FCH-JU). In January 2013, the ENE-FIELD project is launched as the largest European demonstration of fuel cell-based micro-CHP. The five-year demonstration, which is co-funded by (FCH-JU), will deploy up to 1,000 residential fuel cell installations across 12 key member states. The system output electrical and thermal ratings are $1 \mathrm{~kW}$ and $1.4 \mathrm{~kW}$ respectively. The system life time is 40000 hours and its cost is about $€ 9000$, [32].

Fuel cell manufacturer, Ballard Power Co., generates electrical power and heat from CHP PEMFC rated as $1 \mathrm{~kW}$ and $1.52 \mathrm{~kW}$ respectively. The system life time is 40000 hours and its cost is C $\$ 11600$. The company's high-temperature PEM fuel cell is being sold primarily in California, where the Self Generation Incentive Program (SGIP) provides generous funding for fuel cell installations [33].

Another program has been developed to calculate the $\mathrm{COE}$ for the previous systems. Table 5 summarizes the COE for each system according to each system rated output electrical and thermal power, the life time, and the cost. When calculating the running cost, the natural gas is considered as the fueling input. The flow rate of natural gas for residential fuel cell is $0.0066 \mathrm{MMBtu} / \mathrm{kWh}$ [34]. The following exchange rate is considered: $1 €=1.29 \$=1.42 \mathrm{CAD}$.

Table 5: COE of different commercial CHP PEMFC systems in the market.

\begin{tabular}{c|ccccc}
\hline System & $\begin{array}{c}P_{e} \\
{[K W]}\end{array}$ & $\begin{array}{c}P_{\text {th }} \\
{[K W]}\end{array}$ & $\begin{array}{c}\text { Life time } \\
\text { [hours }]\end{array}$ & $\begin{array}{c}\text { System } \\
\text { price }[\$]\end{array}$ & $\begin{array}{c}\text { COE } \\
{[\$ / K W h]}\end{array}$ \\
\hline ENE-FARM & 0.75 & 1.08 & 60000 & 18500 & 0.26 \\
ENE-FIELD & 1 & 1.4 & 40000 & 11520 & 0.19 \\
Ballard Power & 1 & 1.52 & 40000 & 10540 & 0.16 \\
\hline
\end{tabular}

The program results show that the COE ranges are from 0.16 to $0.26 \$ / \mathrm{kWh}$ according to each system specifications and cost. Figure 5 shows the percentage cost of LCC of the FC system within its life time. The analysis shows that the system 
capital cost represents the major cost, while the running cost represents only $29 \%$ of the total LCC.

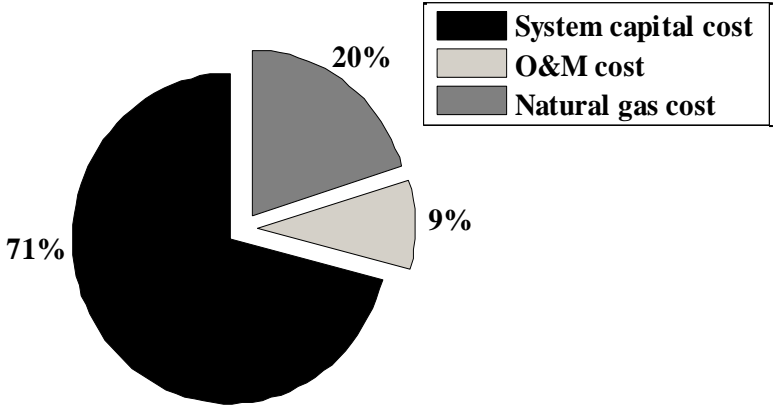

Fig. 5: The percentage cost of LCC for complete CHP PEMFC.

The obtained results are compared to the COE obtained in a previous work by authors [35], for the same residential ratings but supplied from a stand-alone PV (SAPV) system. The comparison shows that using CHP PEMFC system is advantageous since the $\mathrm{COE}$ is cheaper than using SAPV system, which is $1.84 \$ / \mathrm{kWh}$. In addition, the CHP PEMFC system is not dependant on the climate conditions. On the other hand, SAPV does not need any fossil fuels. The main problem of fuel cells is the absence of hydrogen infrastructure to supply hydrogen fuel. On-board hydrogen storage is a major issue and since hydrogen is the fuel, there are concerns about explosions. On the other hand, photovoltaic systems are considered as completely safe, clean, and renewable energy source. It doesn't need infrastructure and hence, it can be used in remote areas.

\section{CONCLUSION}

An economic analysis of a PEMFC system for residential applications is carried out to simply define the size of each component and the COE over the system life time. The FC degradation and the system salvage value are considered. In addition to the electrical output power, the fuel cell thermal output power is taking into consideration for calculating the COE. Two scenarios for economic survey are studied. One scenario is to find the commercial price for each FC component considering that the fuel input is hydrogen. The second scenario is for a complete FC system commercial price considering that the fuel input is natural gas. From the results and discussion, it is found that the COE ranged from $0.16 \$ / \mathrm{kWh}$ to $0.26 \$ / \mathrm{kWh}$ according to each system price, life time, fuelling input, and its electrical and thermal output power. The FC capital cost has a major role in defining the COE over the running cost that includes the O\&M and fuelling cost. Comparing the fuel cell $\mathrm{COE}$ with previous work by the authors, for the same residential ratings but supplied from SAPV, the use of CHP PEMFC system can be cheaper and more reliable power. However, fuel cells use fossil fuel and they have many precautions for hydrogen storage. On the other hand, photovoltaic systems considered as completely safe, clean, sustainable and renewable energy source. More investigation is required to develop hybrid configurations and reduce the capital cost of fuel cells.

\section{ACKNOWLEDGMENT}

The work is supported by the TÁMOP-4.2.2.A-11/1/KONV2012-0041 project. The project is co-financed by the European Union and the European Social Fund.

\section{REFERENCES}

[1] Mekhilef, S., R. Saidur, and A. Safari. "Comparative study of different fuel cell technologies." Renewable and Sustainable Energy Reviews 16.1 (2012): 981-989.

[2] Wang, Yun, et al. "A review of polymer electrolyte membrane fuel cells: Technology, applications, and needs on fundamental research." Applied Energy 88.4 (2011): 981-1007.

[3] Nelson, D. B., M. H. Nehrir, and C. Wang. "Unit sizing and cost analysis of stand-alone hybrid wind/PV/fuel cell power generation systems." Renewable energy 31.10 (2006): 1641-1656.

[4] Kuhn, R., et al. "Dynamic fuel cell gas humidification system." International Journal of Hydrogen Energy 37.9 (2012): 7702-7709.

[5] Harikishan Reddy, E., and S. Jayanti. "Thermal management strategies for a $1 \mathrm{kWe}$ stack of a high temperature proton exchange membrane fuel cell." Applied Thermal Engineering 48 (2012): 465-475.

[6] Zhang, Guangsheng, and Satish G. Kandlikar. "A critical review of cooling techniques in proton exchange membrane fuel cell stacks." International Journal of Hydrogen Energy 37.3 (2012): 2412-2429.

[7] Colozza, A. J., Burke, K. A., \& NASA Glenn Research Center, "Evaluation of a passive heat exchanger based cooling system for fuel cell applications", Cleveland, Ohio: National Aeronautics and Space Administration, Glenn Research Center (2011).

[8] Teymouri Hamzehkolaei, Fatemeh, and Sourena Sattari. "Technical and economic feasibility study of using Micro CHP in the different climate zones of Iran." Energy 36.8 (2011): 4790-4798.

[9] Yu, Yi, et al. "Comparison of degradation behaviors for open-ended and closed proton exchange membrane fuel cells during startup and shutdown cycles." Journal of Power Sources 196.11 (2011): 5077-5083.

[10] Yu, Yi, et al. "A review on performance degradation of proton exchange membrane fuel cells during startup and shutdown processes: causes, consequences, and mitigation strategies." Journal of Power Sources 205 (2012): 10-23.

[11] Zhou, Keliang, J. A. Ferreira, and S. W. H. De Haan. "Optimal energy management strategy and system sizing method for stand-alone photovoltaic-hydrogen systems." International journal of hydrogen energy 33.2 (2008): 477-489.

[12] Hung, Ai-Jen, et al. "Cost analysis of proton exchange membrane fuel cell systems." AIChE Journal 54.7 (2008): 1798-1810.

[13] Fuel Cell Handbook, seventh edition. "EG\&G technical services." Inc., USDOE, 2004.

[14] Graetz, Jason. "New approaches to hydrogen storage." Chemical Society Reviews 38.1 (2009): 73-82.

[15] Verstraete, D., et al. "Hydrogen fuel tanks for subsonic transport aircraft." International Journal of Hydrogen Energy 35.20 (2010): 1108511098.

[16] Wan, Z. M., et al. "Water recovery and air humidification by condensing the moisture in the outlet gas of a proton exchange membrane fuel cell stack." Applied Thermal Engineering 42 (2012): 173-178.

[17] Magistri, L., Traverso, A., Massardo, A. F., \& Shah, R. K. (2006). "Heat exchangers for fuel cell and hybrid system applications", Journal of fuel cell science and technology, 3(2), 111-118.

[18] Ahmed M. Azmy, Simulation and management of distributed generating units using intelligent techniques, Ph.D. thesis, University of DuisburgEssen, Faculty of Engineering, Germany, (2005). 
[19] Carlson, E. J., Kopf, P., Sinha, J., Sriramulu, S., \& Yang, Y. (2005). "Cost Analysis of PEM Fuel Cell for Transportation Systems", National Renewable Energy Laboratory NREL, Report No. NREL/SR-560-39104.

[20] Spendelow, J., and J. Marcinkoski. "Fuel Cell System Cost-2012." US Department of Energy Hydrogen and Fuel Cells Program, Report 12020 (2012).

[21] Bartels, Jeffrey R., Michael B. Pate, and Norman K. Olson. "An economic survey of hydrogen production from conventional and alternative energy sources." International journal of hydrogen energy 35.16 (2010): 8371-8384.

[22] Oh, Si-Doek, et al. "Optimal operation of a 1-kW PEMFC-based CHP system for residential applications." Applied Energy 95 (2012): 93-101.

[23] Matsuura T, et al., "Degradation phenomena in PEM fuel cell with deadended anode", International Journal of Hydrogen Energy, (2013).

[24] Hawkes, A. D., D. J. L. Brett, and N. P. Brandon. "Fuel cell micro-CHP techno-economics: Part 2-Model application to consider the economic and environmental impact of stack degradation." International Journal of Hydrogen Energy 34.23 (2009): 9558-9569.

[25] web site: www.horizonfuelcell.com, accessed on 8/9/2014.

[26] One of the fuel cell R\&D firms in the US: http://fuelcellsetc.com/store/, accessed on 11/9/2014.

[27] Energy Information Administration. U.S. natural gas prices, http://www.eia.gov/dnav/ng/ng_pri_sum_dcu_nus_m.htm

[28] Zoulias, E. I., and N. Lymberopoulos. "Techno-economic analysis of the integration of hydrogen energy technologies in renewable energy-based stand-alone power systems." Renewable Energy 32.4 (2007): 680-696.

[29] Makhmalbaf, Atefe, et al. "Lesson Learned from Technical and Economic Performance Assessment and Benefit Evaluation of CHPFCS." (2014).

[30] http://www.nuvant.com , accessed on 11/9/2014.

[31] http://panasonic.co.jp/corp/news/official.data/data.dir/2013/01/en1301175/en130117-5.html , accessed on 9/9/2014.

[32] http://enefield.eu/ , accessed on 9/9/2014.

[33] http://en.wikiversity.org/wiki/Design_for_the_Environment/Residential_ Micro-cogeneration, accessed on 9/9/2014.

[34] Adams, Alina, "Cost analysis comparison of bloom energy fuel cells with solar energy technology and traditional electric companies", $\mathrm{PhD}$ Thesis, San Jose State University, 2011.

[35] Sherif M., Ahmed M., E. Rashad, "Sizing and Economics Analysis of Standalone PV System for Residential Utilization", MEPCON'14, Cairo, 13-15 December, 2014. 